\title{
Climate control on sulphate and nitrate concentrations in alpine streams of Northern Italy along a nitrogen saturation gradient
}

\author{
M. Rogora ${ }^{1}$, C. Arese $^{2}$, R. Balestrini ${ }^{2}$, and A. Marchetto ${ }^{1}$ \\ ${ }^{1}$ CNR Institute of Ecosystem Study, 28922 Verbania Pallanza, Italy \\ ${ }^{2}$ CNR Water Research Institute, Department of Hydrobiology Applied to Water Pollution, 20047 Brugherio, Milan, Italy
}

Received: 5 December 2006 - Published in Hydrol. Earth Syst. Sci. Discuss.: 11 September 2007

Revised: 30 November 2007 - Accepted: 5 February 2008 - Published: 5 March 2008

\begin{abstract}
The role of meteorology, hydrology and atmospheric deposition on the temporal pattern of $\mathrm{SO}_{4}$ and $\mathrm{NO}_{3}$ concentrations was investigated for three streams draining alpine catchments in Northern Italy.

The study sites lie on a gradient of atmospheric fluxes of $\mathrm{SO}_{4}$ and $\mathrm{NO}_{3}$ (from about 50 to 80 meq $\mathrm{m}^{-2} \mathrm{y}^{-1}$, and from 40 to $90 \mathrm{meq} \mathrm{m}^{-2} \mathrm{y}^{-1}$, respectively). As a consequence of the increasing $\mathrm{N}$ input, the three catchments are also representative of aggrading levels of $\mathrm{N}$ saturation. Different methods of statistical analysis were applied to monthly data for the period 1997-2005 to identify which variables (temperature, precipitation, hydrology, $\mathrm{SO}_{4}$ and $\mathrm{NO}_{3}$ deposition) were the main predictors of water chemistry and its change in time. Hydrological changes and snow cover proved to be the main confounding factors in the response to atmospheric deposition in the River Masino catchment. Its particular characteristics (small catchment area, rapid flushing during runoff and thin soil cover) meant that this site responded without a significant delay to $\mathrm{SO}_{4}$ deposition decrease. It also showed a clear seasonal pattern of $\mathrm{NO}_{3}$ concentration, in response to hydrology and biological uptake in the growing season.

The selected driving variables failed to model the water chemistry at the other study sites. Nevertheless, temperature, especially extreme values, turned out to be important in both $\mathrm{SO}_{4}$ and $\mathrm{NO}_{3}$ export from the catchments. This result might be largely explained by the effect of warm periods on temperature-dependent processes such as mineralization, nitrification and $\mathrm{S}$ desorption.

Our findings suggest that surface waters in the alpine area will be extremely sensitive to a climate warming scenario: higher temperatures and increasing frequency of drought could exacerbate the effects of high chronic $\mathrm{N}$ deposition.
\end{abstract}

Correspondence to: M. Rogora

(m.rogora@ise.cnr.it)

\section{Introduction}

A sharp decrease of sulphur deposition has occurred in the last 15-20 years throughout Europe as a consequence of international agreements in emission control under the Convention on Long Range Transboundary Air Pollution (CLRTAP). These efforts have resulted in a significant widespread recovery of aquatic ecosystems from acidification in several areas of Europe (e.g. Evans et al., 2001; Skjelkvåle et al., 2005). Nevertheless, the recovery in different areas could be masked to a greater or lesser degree according to the role played by confounding factors such as those related to climate change or $\mathrm{N}$ enrichment of surface waters.

A number of studies demonstrated how climate plays a role along with atmospheric deposition in water chemistry and its change in time (e.g. Aber and Driscoll, 1997; Eimers and Dillon, 2002; Aber et al., 2002; Mitchell et al., 2006). In temperate northern ecosystems changes in snow cover associated with climate change might be a major factor affecting the nature and the extent of hydrological nutrient losses. Freezing and thawing cycles, for instance, can have marked effects on biotic activity and nutrient release in upland soils, leading to high concentrations of nitrate in stream waters after soil freezing episodes (Mitchell et al., 1996). Climate warming may also delay recovery from acidification, enhancing $\mathrm{N}$ mineralisation processes and increasing $\mathrm{NO}_{3}$ leaching from soils to surface water (Lükewille and Wright, 1997). In fact, rates of both $\mathrm{N}$ mineralization and nitrification are sensitive to changes in air temperature and soil moisture (Stark and Hart, 1997). The CLIMEX project showed that increased temperature resulted in increased flux of $\mathrm{NO}_{3}$ to running waters, and this effect may shift the seasonal pattern of $\mathrm{NO}_{3}$ flux in streams and rivers (Wright, 1998). Furthermore, the effect of warm summers and droughts on $\mathrm{NO}_{3}$ leaching can persist over several years (Reynolds et al., 1992).

Published by Copernicus Publications on behalf of the European Geosciences Union. 
Table 1. Main characteristics of the study rivers.

\begin{tabular}{|c|c|c|c|c|c|c|c|c|c|}
\hline \multirow[t]{2}{*}{ River } & \multicolumn{2}{|c|}{ Geographical coordinates } & \multirow{2}{*}{$\begin{array}{c}\text { Mean altitude } \\
\text { m a.s.l. }\end{array}$} & \multirow{2}{*}{$\begin{array}{l}\text { Length } \\
\text { km }\end{array}$} & \multirow{2}{*}{$\begin{array}{l}\text { Catchment } \\
\text { area } \mathrm{km}^{2}\end{array}$} & \multirow{2}{*}{$\begin{array}{l}\text { Average discharge } \\
\mathrm{m}^{3} \mathrm{~s}^{-1}\end{array}$} & \multirow{2}{*}{$\begin{array}{c}\text { Annual } \\
\text { rainfall mm }\end{array}$} & \multirow{2}{*}{$\begin{array}{l}\text { Total } \mathrm{N} \text { deposition } \\
\text { meq } \mathrm{m}^{-2} \mathrm{y}^{-1}\end{array}$} & \multirow{2}{*}{$\begin{array}{l}\mathrm{SO}_{4} \text { deposition } \\
\text { meq } \mathrm{m}^{-2} \mathrm{y}^{-1}\end{array}$} \\
\hline & Lat N & Long E & & & & & & & \\
\hline Masino (Mas) & $46^{\circ} 14^{\prime}$ & $9^{\circ} 35^{\prime}$ & 2030 & 6.3 & 25.2 & - & 1681 & 80 & 51 \\
\hline Cannobino (Can) & $46^{\circ} 04^{\prime}$ & $8^{\circ} 42^{\prime}$ & 1057 & 27 & 110 & 5.9 & 2230 & 161 & 62 \\
\hline S. Bernardino (Sbe) & $45^{\circ} 56^{\prime}$ & $8^{\circ} 43^{\prime}$ & 1228 & 29 & 131 & 6.3 & 1730 & 190 & 81 \\
\hline
\end{tabular}

In this paper we focus on the temporal pattern of $\mathrm{SO}_{4}$ and $\mathrm{NO}_{3}$ concentrations in three selected streams located in the alpine area of Northern Italy. Despite their location far from the main emission sources, these remote sites are nonetheless threatened by high deposition of pollutants (Mosello et al., 1999; Balestrini et al., 2006). Because the selected rivers are located along a gradient of $\mathrm{N}$ and $\mathrm{S}$ atmospheric inputs, the comparison of nitrate and sulphate variations in their waters is of great interest in making hypotheses about the future impact of global changes. Given the relative similarity of soil characteristics at the selected sites, the potential effect of climate on water chemistry at the most impacted sites (Rivers Cannobino and S. Bernardino) should give some insight into the evolution of the most pristine one (River Masino). On the other hand, the main processes identified at the least impacted site should make it possible to reconstruct the main steps that have lead to the present condition of the polluted catchments.

Data used in this study have been collected in the framework of research projects dealing with atmospheric deposition of sulphur and nitrogen compounds and its effects on surface water. Like most of Europe, the alpine area experienced a sharp decline of $\mathrm{SO}_{4}$ deposition in the last two decades. Nitrogen deposition, on the other hand, increased slightly or remained stable (Rogora et al., 2006). Deposition of inorganic $\mathrm{N}$, as the sum of ammonium and nitrate, is extremely high in this area (150-200 meq $\left.\mathrm{m}^{-2} \mathrm{y}^{-1}\right)$, due to a combination of high precipitation (1700-2200 mm) and elevated concentration of $\mathrm{N}$ compounds in atmospheric deposition (Rogora et al., 2006).

The chemistry of Rivers Cannobino and S. Bernardino, tributaries of Lake Maggiore, has been monitored by the CNR Institute of Ecosystem Study since the 1970s in the framework of studies on eutrophication and recovery of the lake (Mosello et al., 2001). River Cannobino is also included in the ICP Waters network (International Co-operative Programme on Assessment and Monitoring of Acidification of Rivers and Lakes), set up under the CLRTAP (Mosello et al., 1999). Like several other sites in the same area, the Cannobino and the S. Bernardino catchments have undergone $\mathrm{N}$ saturation with consequent leaching of $\mathrm{NO}_{3}$ to surface waters. The huge flux of $\mathrm{N}$ from atmospheric deposition, together with a low net ecosystem production in the old-growth forest covering the catchments have been proposed as the main causes for the $\mathrm{N}$ saturation status (Rogora and Mosello, 2007).
The water chemistry of River Masino has been analysed since 1997 within the CONECOFOR Project, part of the International Cooperative Programme on Assessment and Monitoring of Air Pollution Effects on Forests (ICP Forests), also set up under the terms of the CLRTAP. Since 1987, the Water Research Institute and the Regional Forest Board have been working together to establish a monitoring network in Lombardy to evaluate the relationships between atmospheric deposition and forest ecosystem responses. The investigations focused on high elevation catchments, particularly sensitive to environmental perturbations due to high levels of precipitation, acidic soils, and rapid hydrological flushing during runoff (Balestrini and Tagliaferri, 2001). Additional research is currently being performed in the Val Masino area, with the aim of improving understanding of the effectiveness of the biological compartment in modifying the fluxes of atmospheric elements, and to investigate the role of nitrogen both as an acidifying element and as a nutrient (Balestrini et al., 2006).

This study investigated the temporal pattern of $\mathrm{SO}_{4}$ and $\mathrm{NO}_{3}$ concentrations in river water. In this connection we focused on the relationship between meteorological variables (temperature and precipitation), hydrology, $\mathrm{SO}_{4}$ and $\mathrm{NO}_{3}$ deposition and river chemistry at three sites representative of different hydrological regimes and $\mathrm{N}$ saturation levels. Climate-chemistry relationships were investigated at different temporal levels: trends, seasonal dependence, episodes or short-term changes. The main aims of the study were: 1 ) to analyse water chemistry response to meteorology, hydrology and atmospheric deposition; 2) to identify which meteorological variables were the best predictors of water chemistry changes and the major confounding factors in acidification recovery; 3 ) to formulate some hypotheses about the possible effect of climate change on the response of the site to atmospheric deposition of $\mathrm{S}$ and $\mathrm{N}$ compounds.

\section{Study area and methods}

The study sites are located in the alpine area of Northern Italy, in the regions of Lombardy (1 site) and Piedmont (2 sites). The main characteristics of the study sites are sketched in Table 1.

Rivers Cannobino and S. Bernardino are located in the watershed of Lake Maggiore, one of the largest Italian lakes. The river catchments are mainly forested (about $80 \%$ of the 
total catchment area) and located at altitudes between about 200 and $3000 \mathrm{~m}$ a.s.l. (Table 1). Both catchments are sparsely populated and do not include any intensive industrial, stockrearing or agricultural activity. The morphological characteristics of the area do not permit extensive agriculture, so that the use of $\mathrm{N}$ fertilizers is negligible. These rivers have been sampled monthly and analysed for the major chemical determinants since 1971 (Mosello et al., 2001).

Masino is an alpine stream located in a remote highaltitude area, with a catchment mainly consisting of bare rocks and meadows (75\% of the total area) (Balestrini et al., 2002). The catchment considered in this study comprises the upper basin of the River Masino, where the monitoring plots of the CONECOFOR Project are located (Balestrini et al., 2002). Stream water samples at this site were collected weekly from the snowmelt (March or April) to November. Sampling was interrupted during the winter period since the stream was frozen and nearly dry. The depth of the water was measured by a hydrometric gauge placed at the sampling site. The arithmetic means of weekly data (concentrations and water levels) were used to obtain monthly values.

Meteorological data used in the study were collected as follows: for Rivers Cannobino and S. Bernardino, mean values of temperature and precipitation from a number of meteorological stations in the catchments were used. This allowed us to obtain representative values for the whole catchment, in consideration of the wide area and the steep altitudinal gradient.

For River Masino temperature and precipitation data collated at the meteorological station in the monitoring plot were used. Monthly mean values of maximum (Tx), minimum $(\mathrm{Tn})$, mean $(\mathrm{Tm})$ temperature and precipitation amount $(\mathrm{mm})$ were considered for all the sites.

As to hydrological data, monthly mean values of water discharge $(\mathrm{Q})$ were used for the Cannobino and the S. Bernardino, while only water level data (Hidr) were available for the Masino site. For the latter site mean annual values of snow cover were also considered in the analysis.

Atmospheric deposition data were obtained from the atmospheric deposition sampling sites of Pallanza (River S. Bernardino), Lunecco (River Cannobino) and Val Masino (River Masino). At these sites atmospheric deposition samples were collected weekly and analysed for the main chemical variables (Mosello et al., 2001; Balestrini et al., 2002). Deposition values were calculated by multiplying monthly weighted mean concentrations and monthly precipitation amount.

Monthly values were used for all variables in the elaboration. In order to compare the temporal pattern of $\mathrm{SO}_{4}$ and $\mathrm{NO}_{3}$ in the three rivers, only the common period 1997-2005 was considered here.

Various methods of statistical analysis were applied to chemical, meteorological and hydrological data in order to describe the main temporal patterns and investigate climatechemistry relationships. Seasonal dependence was tested by
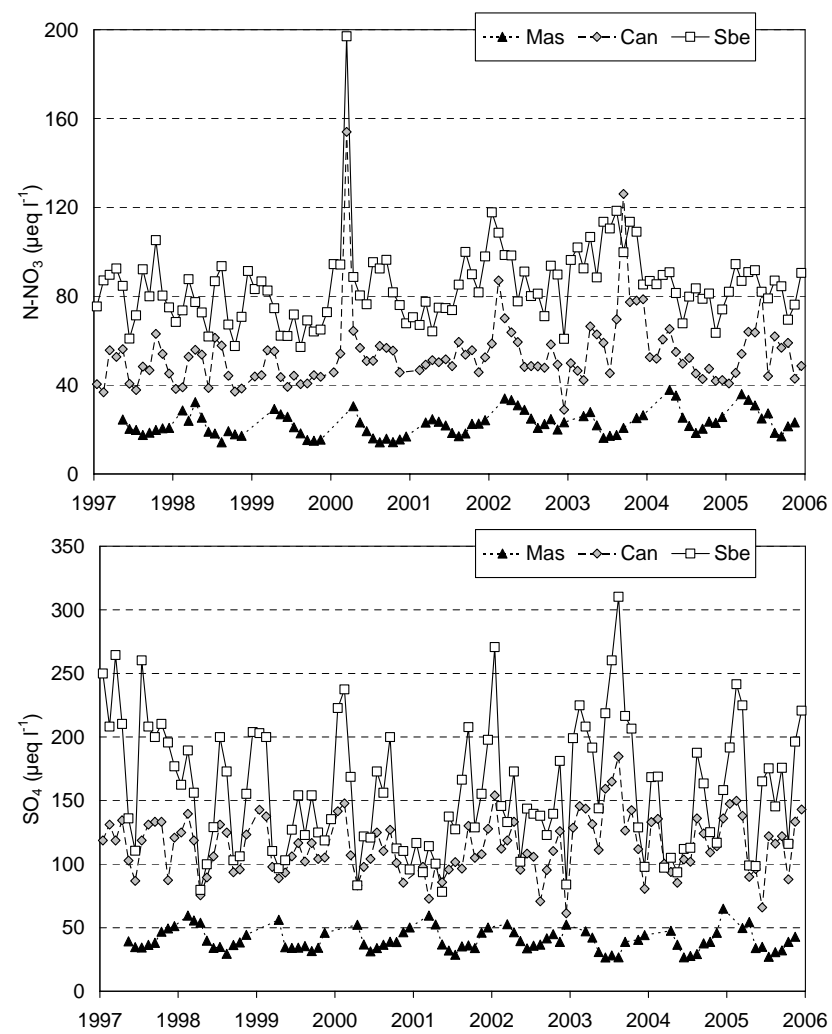

Fig. 1. Long-term dynamics (1997-2005) of monthly $\mathrm{NO}_{3}$ (upper panel) and $\mathrm{SO}_{4}$ (lower panel) concentrations in the study rivers. For the abbreviations see Table 1 .

means of the Kruskall Wallis test (months as groups). The test was used here simply as a way to check whether or not the means among groups were significantly different from one another. Trend analysis was performed with the Seasonal Kendall Test (Hirsch et al., 1982), using the modified procedure described by Hirsch and Slack (1984) to take serial correlation into account. Trend slopes (B) were calculated according to Sen (1968). Cross-correlation function was used to assess the relationships between chemical data and explanatory variables. Before calculating $\mathrm{CC}$, repeated loess smoothing (Cleveland et al., 1990) was applied to time series data to remove the seasonal signal from the data. Stepwise linear regression (backward selection of variables) was used as a tool to identify the best predictors of water chemistry among the selected explanatory variables. The model selection was performed on the basis of the Akaike's information criterion (AIC). All statistical analyses were performed with the following softwares: Brodgar vers. 2.5.1 (Highland Statistics Ltd) and S-plus 2000 (Math Soft). 


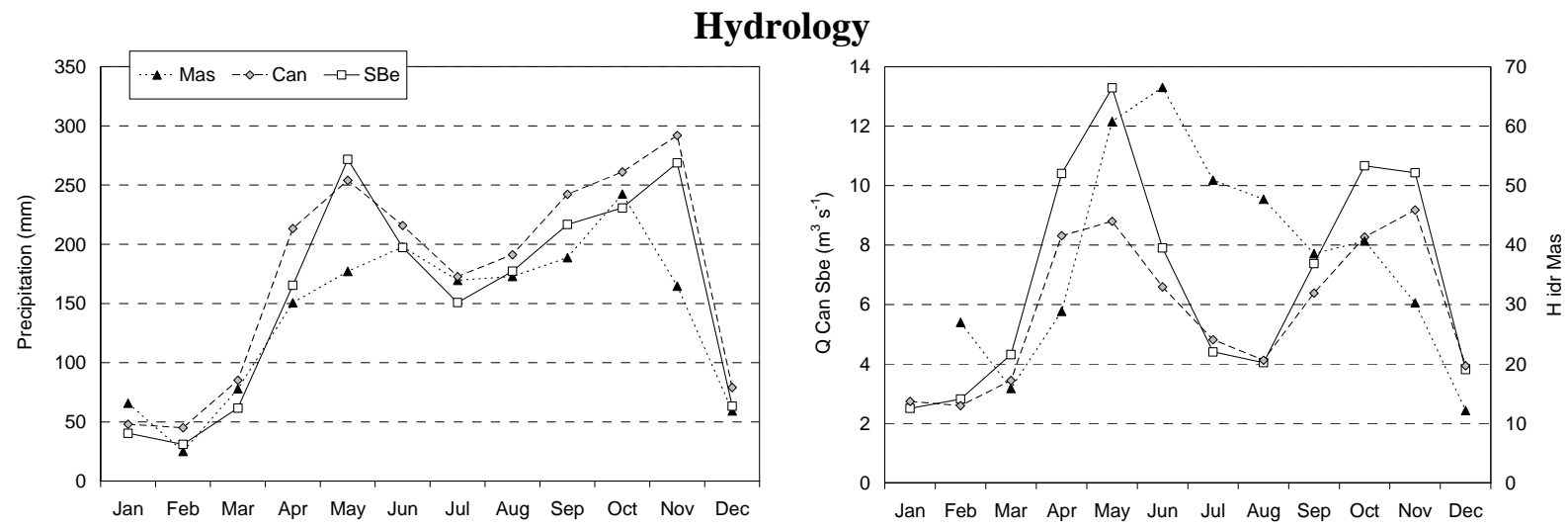

Atmospheric deposition
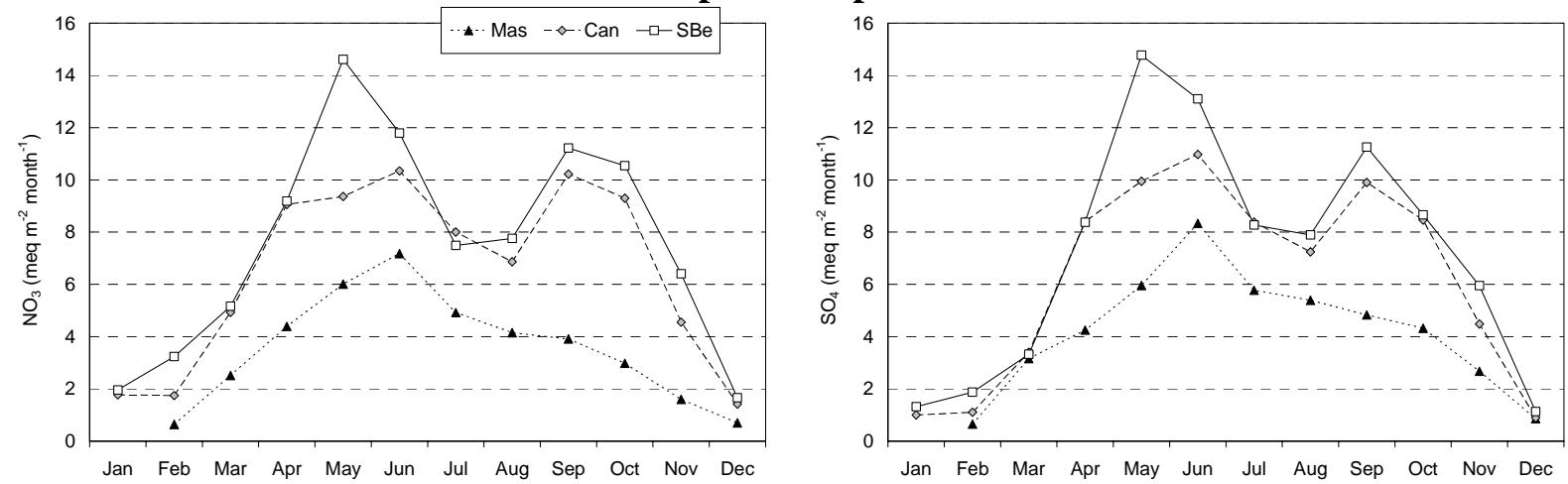

Fig. 2. Monthly mean values (1997-2005) of precipitation amount and discharge (hydrometric level for River Masino) (upper panel), and $\mathrm{NO}_{3}$ and $\mathrm{SO}_{4}$ deposition (lower panel) at the study sites Masino, Cannobino and $\mathrm{S}$. Bernardino (Table 1).

\section{Results and discussion}

\subsection{Water chemistry and seasonality}

The dynamics of monthly $\mathrm{NO}_{3}$ and $\mathrm{SO}_{4}$ concentrations in the study rivers since 1997 are shown in Fig. 1. The study sites lie on a gradient of atmospheric fluxes of $\mathrm{SO}_{4}$ and $\mathrm{NO}_{3}$ : annual mean $\mathrm{SO}_{4}$ deposition increases from $51 \mathrm{meq} \mathrm{m}{ }^{-2} \mathrm{y}^{-1}$ at the Masino site to 62 (River Cannobino) and to 81 (River $\mathrm{S}$. Bernardino). The corresponding values for $\mathrm{NO}_{3}$ deposition are 40,78 and 90 meq $^{-2} \mathrm{y}^{-1}$, respectively.

Water chemistry clearly reflects the atmospheric inputs: River Masino is characterised by distinctly lower concentrations of both $\mathrm{SO}_{4}$ and $\mathrm{NO}_{3}$ compared to Rivers Cannobino and S. Bernardino (Fig. 1). Annual mean concentrations of $\mathrm{SO}_{4}$ were 43,115 and $158 \mu \mathrm{eq} 1^{-1}$, respectively; the corresponding values for $\mathrm{NO}_{3}$ were 23,54 and $85 \mu \mathrm{eq} 1^{-1}$.

Monthly average values (1997-2005) of selected explanatory variables (precipitation amount, discharge, $\mathrm{SO}_{4}$ and $\mathrm{NO}_{3}$ deposition) are shown in Fig. 2, while the seasonal patterns of $\mathrm{NO}_{3}$ and $\mathrm{SO}_{4}$ in river water are plotted in Fig. 3 by means of box and whiskers plots.

The seasonal dependency resulting from the KruskallWallis Test, turned out to be highly significant $(\mathrm{p}<0.0001)$ for all the variables in the case of River Masino. Results were remarkably similar at the other sites, with a less evident seasonal dependency for water chemistry: only slightly significant $(\mathrm{p}<0.01)$ for $\mathrm{SO}_{4}$ and not significant at all for $\mathrm{NO}_{3}$ (Table 2).

The precipitation regime was quite similar at the three sites, with minimum precipitation amount in winter and maxima in spring and autumn. In contrast, the sites differed from the point of view of the hydrological regime, the discharge of the Cannobino and the S. Bernardino being much more related to precipitation amount $(\mathrm{R}=0.81-0.82, \mathrm{p}<0.001)$ than in the case of the River Masino (Fig. 2).

$\mathrm{NO}_{3}$ and $\mathrm{SO}_{4}$ concentrations in River Masino showed an evident seasonal pattern (Figs. 1 and 3), with a limited difference from one year to the next. On the other hand, there was high interannual variability in the Cannobino and the S. Bernardino, with $\mathrm{NO}_{3}$ peaks usually occurring in different months of the year (Fig. 1). $\mathrm{NO}_{3}$ fluctuations in these rivers were not related to $\mathrm{NO}_{3}$ deposition $(\mathrm{R}=0.06-0.14, \mathrm{p}>0.05)$, but depended on hydrology or biological processes taking place in the soil: for instance the spring maxima may derive from the leaching of previously stored $\mathrm{N}$ in the soils in winter months (Sickman et al., 2002; Murdoch et al., 1998; Mitchell et al., 2003). 

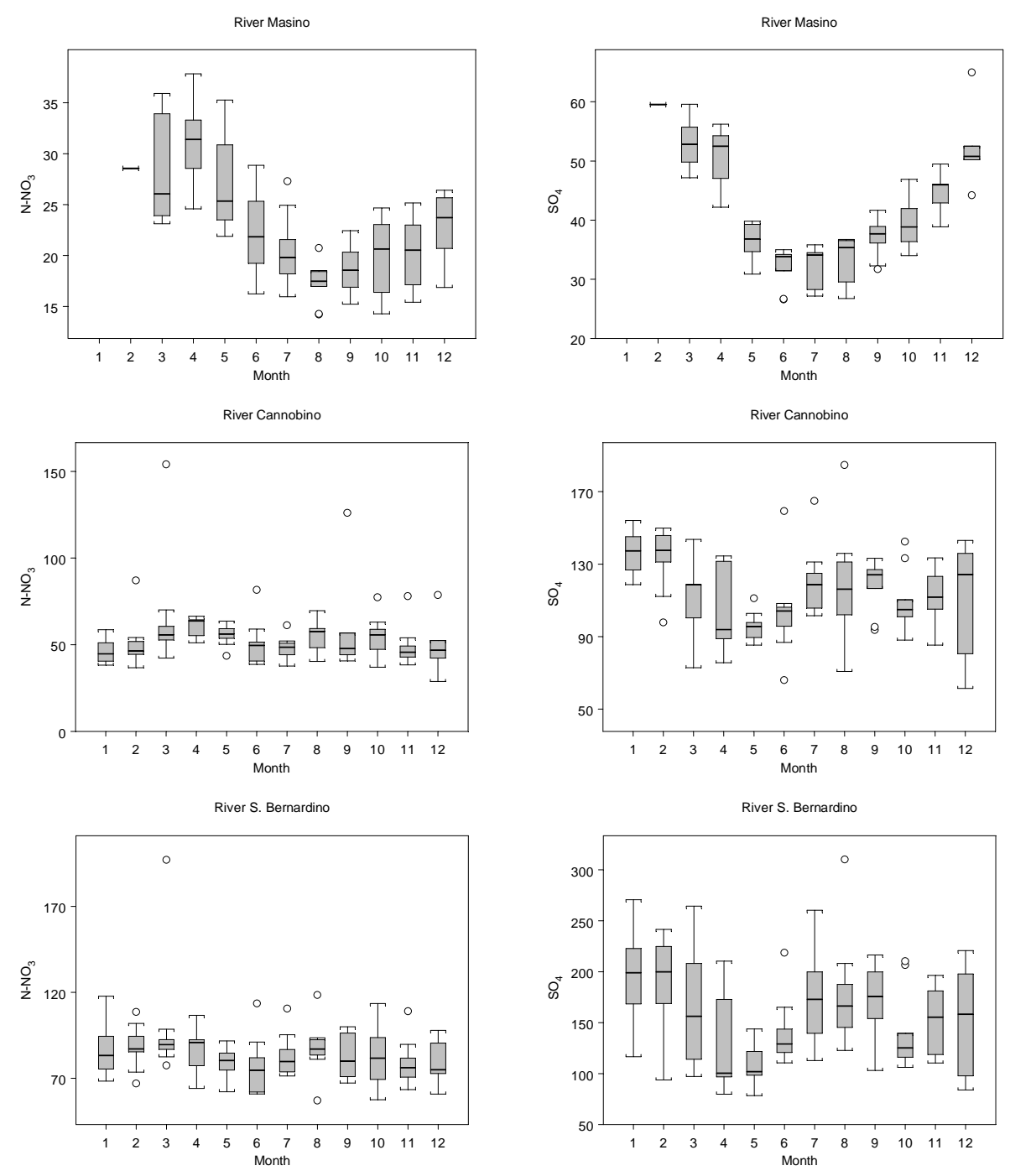

Fig. 3. Box and whisker plots showing the seasonal pattern of $\mathrm{NO}_{3}$ (left panel) and $\mathrm{SO}_{4}$ (right panel) concentrations (in $\mu$ eq $1^{-1}$ ) in the study rivers. Boxes show the limits of the middle half of the data; the line inside the box represents the median. Whiskers are drawn to the nearest value not beyond a standard span from the quartiles; points beyond are outliers (circles). The standard span is 1.5 times the Inter-Quartile Range.

For River Cannobino a biological control of $\mathrm{NO}_{3}$ concentrations can be hypothesised for summer months (June-July), even though this effect has seemed to be less and less evident in recent years (Rogora and Mosello, 2007). $\mathrm{NO}_{3}$ levels in River S. Bernardino never went below $50 \mu \mathrm{eq} 1^{-1}$, confirming an advanced level of $\mathrm{N}$ saturation (stage 3 according to Stoddard's model of N saturation; Stoddard and Traaen, 1994).

$\mathrm{NO}_{3}$ data for River Masino seem to indicate a tendency towards increasing values during the winter months (Fig. 3). At the onset of snowmelt, the draining of the upper organic soil layers can result in a small pulse in stream water $\mathrm{NO}_{3}$ concentration (Campbell et al., 1995; Stottlemeyer, 1997). Melting snow characterised by low $\mathrm{NO}_{3}$ concentrations and biological processes consuming $\mathrm{N}$ could explain the declin- ing level during spring and summer. $\mathrm{NO}_{3}$ concentrations in stream water were lower than those in precipitation from May to September and higher during the winter months. The release of soil inorganic $\mathrm{N}$ to stream water can become more important than atmospheric deposition in the cold season (fall and winter) and during the onset of snowmelt, which generally occurs in April. Other studies on snowmeltdominated streams underline the importance of soil water flushing in influencing stream water chemistry (Foster et al., 1989; Arthur and Fahey, 1993; Creed et al., 1996; Stottlemeyer, 1997). $\mathrm{NO}_{3}$ levels never below $10 \mu$ eq $1^{-1}$ and occasionally over $40 \mu \mathrm{eq} 1^{-1}$, suggest, on the base of Stoddard's approach (Stoddard and Traaen, 1994), that a certain level of $\mathrm{N}$ saturation (stage 2) can be hypothesized also for this site. On the other hand, the substantially lower inorganic $\mathrm{N}$ 
Table 2. Results of the Kruskall-Wallis Test (KWT; months as grouping variable) and the Seasonal Kendall Test (SKT) applied to monthly data (1997-2005). B: trend's slope according to Sen (1968). Significance levels: *** $p<0.0001 ; * * p<0.001 ; * p<0.01 ;$ n.s. not significant. Abbreviations as follows: $\mathrm{mm}=$ precipitation amount; $\mathrm{Q}=$ discharge; $\mathrm{Hidr}=$ hydrometric level; $\mathrm{NO}_{3}$ river and $\mathrm{SO}_{4} \mathrm{river}_{=} \mathrm{NO}_{3}$ and $\mathrm{SO}_{4}$ concentrations in river water; $\mathrm{NO}_{3}$ rain and $\mathrm{SO}_{4}$ rain $=\mathrm{NO}_{3}$ and $\mathrm{SO}_{4}$ concentrations in atmospheric deposition; $\mathrm{NO}_{3}$ dep and $\mathrm{SO}_{4}$ dep = $\mathrm{NO}_{3}$ and $\mathrm{SO}_{4}$ fluxes. $\mathrm{Tn}=$ minimum temperature; $\mathrm{Tx}=$ maximum temperature; $\mathrm{Tm}=$ mean temperature.

\begin{tabular}{lllrlrrrrrr}
\hline & \multicolumn{3}{c}{ Masino* $^{*}$} & \multicolumn{3}{c}{ Cannobino } & \multicolumn{3}{c}{ S. Bernardino } \\
\hline & KWT & SKT & B & KWT & SKT & B & KWT & SKT & B \\
\hline $\mathrm{mm}$ & $* * *$ & $* *$ & -4.605 & $* *$ & n.s. & -0.625 & $* * *$ & n.s. & -1.031 \\
$\mathrm{Q}-\mathrm{Hidr}$ & $* * * 1$ & $* * *$ & -2.809 & $* *$ & $* * *$ & 0.447 & $*$ & n.s. & 0.058 \\
$\mathrm{NO}_{3}$ river & $* * * 1$ & $* * *$ & 0.658 & n.s. & $* * *$ & 1.285 & n.s & $* *$ & 1.231 \\
$\mathrm{NO}_{3}$ rain & $* * *$ & n.s. & -0.131 & $* *$ & n.s. & -0.319 & $*$ & n.s. & -0.214 \\
$\mathrm{NO}_{3}$ dep & $* * *$ & n.s. & -0.081 & $* * *$ & n.s. & -0.110 & $* *$ & n.s. & -0.122 \\
$\mathrm{SO}_{4}$ river & $* * * 1$ & $* * *$ & -0.541 & $*$ & n.s. & 0.999 & $*$ & n.s. & 0.208 \\
$\mathrm{SO}_{4}$ rain & $* * *$ & $* * *$ & -0.849 & $* * *$ & $* * *$ & -1.991 & $* * *$ & $* *$ & -2.086 \\
$\mathrm{SO}_{4}$ dep & $* * *$ & $* * *$ & -0.286 & $* * *$ & $*$ & -0.237 & $* * *$ & $*$ & -0.273 \\
$\mathrm{Tn}$ & $* * *$ & n.s. & -0.090 & $* * *$ & n.s. & -0.001 & $* * *$ & n.s. & -0.006 \\
$\mathrm{Tx}$ & $* * *$ & n.s. & 0.011 & $* * *$ & n.s. & 0.037 & $* * *$ & $*$ & 0.138 \\
$\mathrm{Tm}$ & $* * *$ & n.s. & -0.072 & $* * *$ & n.s. & 0.052 & $* * *$ & n.s. & -0.0204 \\
\hline
\end{tabular}

1 winter months excluded

concentration measured in the soil solution of mineral horizons (Balestrini et al., 2006), could indicate a lack of connection between the deeper soil water draining the forest ecosystem and the stream water. Alternatively, it might suggest that the stream water chemistry, integrating prevailing processes acting in the entire catchment, also reflects the hydrologic contribution of the higher parts of the catchment, where the massive presence of bare rocks limits the retention of atmospheric $\mathrm{N}$ inputs.

The seasonal pattern of $\mathrm{SO}_{4}$ concentrations in the Cannobino and the $\mathrm{S}$. Bernardino was inversely related to discharge $(\mathrm{R}=-0.44$ and -0.56 , respectively, $\mathrm{p}<0.001)$, showing that dilution/concentration are the main processes controlling $\mathrm{SO}_{4}$ variation at these sites. River Masino exhibited higher $\mathrm{SO}_{4}$ levels in April, a rapid decrease to the summer months followed by an increase from the beginning of fall to the frozen period (Fig. 3). As in the other streams, this trend mirrored discharge $\left(\mathrm{R}=-0.63, \mathrm{p}<0.001\right.$, between $\mathrm{SO}_{4}$ and Hidr), which reached a maximum in summer and a minimum in winter (Fig. 2).

\subsection{Trends}

Results of the trend analysis performed with the Seasonal Kendall Test (SKT) are shown in Table 2 together with the trend's slope (B) calculated according to Sen (1968). Precipitation amount decreased significantly in the Masino area in the study period, determining a sharp decrease in runoff. Low hydrometric levels were recorded especially in the last few years of the record (2003-2005), with a tendency towards more severe droughts than in previous years.
A significant increasing trend of water discharge was detected for River Cannobino. Because there was little change in the annual mean values, the SKT result was due to the relatively high discharge values recorded in the winters of 2003-2005. In fact the trend calculated separately for each season proved to be highly significant in winter $(\mathrm{p}<0.0001)$ and not significant in the other periods. Winter precipitation and snow cover in the upper part of the watershed were extremely scarce in the last few years of the record. This factor, coupled with mild winter temperatures, may have determined an increase in runoff in the winter period.

Temperature data did not show any significant trend, apart from a slight increase in the maximum temperature for River S. Bernardino. The lack of significant trends in temperature values was undoubtedly due to the short time period considered in the study; the analysis of long-term data series (19302000) for the same area clearly show increasing trends of temperature, and also suggest that it is mainly in the last 30 years that this tendency towards warming has emerged (Rogora et al., 2004).

An increase of $\mathrm{NO}_{3}$ levels in stream water was detected $\left(\mathrm{p}<0.001 ; 0.7<\mathrm{B}<1.3 \mu \mathrm{eq}^{-1} \mathrm{y}^{-1}\right)$, despite the lack of a significant trend in both $\mathrm{NO}_{3}$ concentrations in rain and $\mathrm{NO}_{3}$ deposition (Table 2). The lack of a significant trend in $\mathrm{NO}_{3}$ deposition at the study sites confirmed results obtained on a broader scale: trends of both $\mathrm{NO}_{3}$ concentrations and fluxes did not show a uniform pattern in the alpine area, and especially in the foothills of the Alps the high amounts of precipitation still determine huge deposition fluxes of $\mathrm{N}$ (Rogora et al., 2006). 
An increasing trend of $\mathrm{NO}_{3}$ levels in surface waters has been observed in several rivers and lakes in the alpine and subalpine areas of Northern Italy and $\mathrm{N}$ saturation has been suggested as the main reason for these trends (Mosello et al., 2001; Rogora et al., 2001). The lack of a significant seasonality in $\mathrm{NO}_{3}$ levels, and hence of a reduced $\mathrm{N}$ retention capacity even in the growing season, confirmed this hypothesis for the Cannobino and the S. Bernardino. In the case of River Masino, the significant decrease in water level certainly also played a role in $\mathrm{NO}_{3}$ increase, as shown by the weak, though significant correlation between these two variables $(\mathrm{R}=-0.29 ; \mathrm{p}<0.01)$.

Since there was a marked seasonal dependency in both stream chemistry and hydrology, the Mann-Kendall test was also applied on weekly data available for the Masino site. Three sub-periods were considered: snow melt (April-May), summer (July-August) and autumn (October-December). A significant increase of $\mathrm{NO}_{3}$ was detected during snowmelt $(\mathrm{p}<0.001, \mathrm{~B}=0.939)$ and in autumn $(\mathrm{p}<0.0001, \mathrm{~B}=0.857)$, but not in the summer months when the biological activity is most intense. The same analysis performed on hydrometric height revealed significant decreases $(\mathrm{p}<0.01 ;-3.6<\mathrm{B}<-$ $2.1)$ in all three periods. A significant negative correlation emerged between $\mathrm{NO}_{3}$ and hydrometric height during AprilMay $(\mathrm{R}=-0.43 ; \mathrm{p}<0.01)$ and October-December $(\mathrm{R}=-0.61$; $\mathrm{p}<0.001)$. This suggests that the biological compartment is still able to limit the availability of inorganic nitrogen during summer, while, in the rest of the year, nitrate release is partly controlled by physical processes.

$\mathrm{SO}_{4}$ decreased significantly only in River Masino $(\mathrm{p}<0.001)$, as a response to the rapid decrease of both $\mathrm{SO}_{4}$ concentration in rain and $\mathrm{SO}_{4}$ deposition (Table 2). The trend slope of $\mathrm{SO}_{4}$ deposition was very similar at the three sites (between -0.24 and -0.29 meq $^{-2} \mathrm{y}^{-1}$, corresponding to an overall decrease of $2.1-2.6$ meq m$^{-2}$ in $1997-$ 2005); but in relative terms the decrease was of about $5.6 \%$ at the Masino site compared to $2.8 \%$ in the Cannobino and $\mathrm{S}$. Bernardino. It must be emphasised that a much greater decrease of $\mathrm{SO}_{4}$ deposition has occurred in the alpine area since the 1980s, with the sharpest decrease in the late 80s, followed by a slight decrease in the 90s (Rogora et al., 2006).

\subsection{Climate-chemistry relationships}

The relationships between water chemistry $\left(\mathrm{SO}_{4}\right.$ and $\mathrm{NO}_{3}$ concentrations) and the selected explanatory variables were also investigated with cross-correlation (CC) analysis (Table 3). Because most variables showed a significant seasonal dependency, we applied repeated loess smoothing (span width 0.4 ) to all the data. This allowed us to investigate the temporal correlations among the time series, especially short-term climate effects, avoiding spurious correlations deriving from a common seasonal pattern. Highly significant climate-chemistry relationships were found when the two time series co-varied and maxima and minima were encoun-
Table 3. Results of cross-correlation analysis applied to smoothed (repeated loess smoothing, span width 0.4) data series (water chemistry and explanatory variables) of the three sites. Significant correlations are in bold. Abbreviations as in Table 2.

\begin{tabular}{|c|c|c|}
\hline & $\mathrm{NO}_{3}$ river & $\mathrm{SO}_{4}$ river \\
\hline \multicolumn{3}{|l|}{ Masino } \\
\hline $\mathrm{mm}$ & -0.75 & 0.34 \\
\hline $\mathrm{H}$ idr & -0.57 & -0.03 \\
\hline $\operatorname{Tn}$ & -0.17 & -0.18 \\
\hline Tx & 0.12 & -0.31 \\
\hline $\mathrm{Tm}$ & -0.11 & -0.23 \\
\hline $\mathrm{NO}_{3}$ rain & 0.38 & - \\
\hline $\mathrm{SO}_{4}$ rain & - & 0.54 \\
\hline $\mathrm{NO}_{3}$ dep & -0.68 & - \\
\hline $\mathrm{SO}_{4}$ dep & - & 0.38 \\
\hline \multicolumn{3}{|l|}{ Cannobino } \\
\hline $\mathrm{mm}$ & -0.35 & -0.66 \\
\hline Q & 0.01 & 0.15 \\
\hline Tn & 0.18 & 0.56 \\
\hline Tx & 0.29 & 0.72 \\
\hline $\mathrm{Tm}$ & 0.30 & 0.76 \\
\hline $\mathrm{NO}_{3}$ rain & -0.20 & - \\
\hline $\mathrm{SO}_{4}$ rain & - & -0.11 \\
\hline $\mathrm{NO}_{3}$ dep & -0.14 & - \\
\hline $\mathrm{SO}_{4}$ dep & - & -0.61 \\
\hline \multicolumn{3}{|l|}{ S. Bernardino } \\
\hline $\mathrm{mm}$ & -0.05 & -0.36 \\
\hline Q & -0.24 & -0.72 \\
\hline Tn & 0.38 & 0.11 \\
\hline Tx & 0.59 & 0.60 \\
\hline $\mathrm{Tm}$ & 0.55 & 0.63 \\
\hline $\mathrm{NO}_{3}$ rain & -0.16 & - \\
\hline $\mathrm{SO}_{4}$ rain & - & 0.26 \\
\hline $\mathrm{NO}_{3}$ dep & -0.13 & - \\
\hline $\mathrm{SO}_{4}$ dep & - & -0.06 \\
\hline
\end{tabular}

tered at the same time e.g. maxima in $\mathrm{NO}_{3}$ or $\mathrm{SO}_{4}$ levels in correspondence to the highest temperatures (or the lowest in case of a negative relationship).

$\mathrm{NO}_{3}$ levels in River Masino were significantly correlated to precipitation amount $(\mathrm{CC}=-0.75)$, and hydrometric level $(\mathrm{CC}=-0.57)$. Since the snowmelt dominates the annual stream hydrograph, these correlations could be interpreted taking account of the influence of the extreme rainy events occurring during late summer and autumn when the $\mathrm{NO}_{3}$ temporal pattern is mainly driven by dilution processes. For example, the minimum nitrate concentrations (10 and $12 \mu \mathrm{eq} 1^{-1}$ ) in the 8-year period were measured during the floods of November 1999 and October 2000, when the hydrometric height was $140 \mathrm{~cm}$ and $80 \mathrm{~cm}$, respectively. Nitrate increase in autumn associated with increased precipitation has been reported in the literature mostly from areas with 

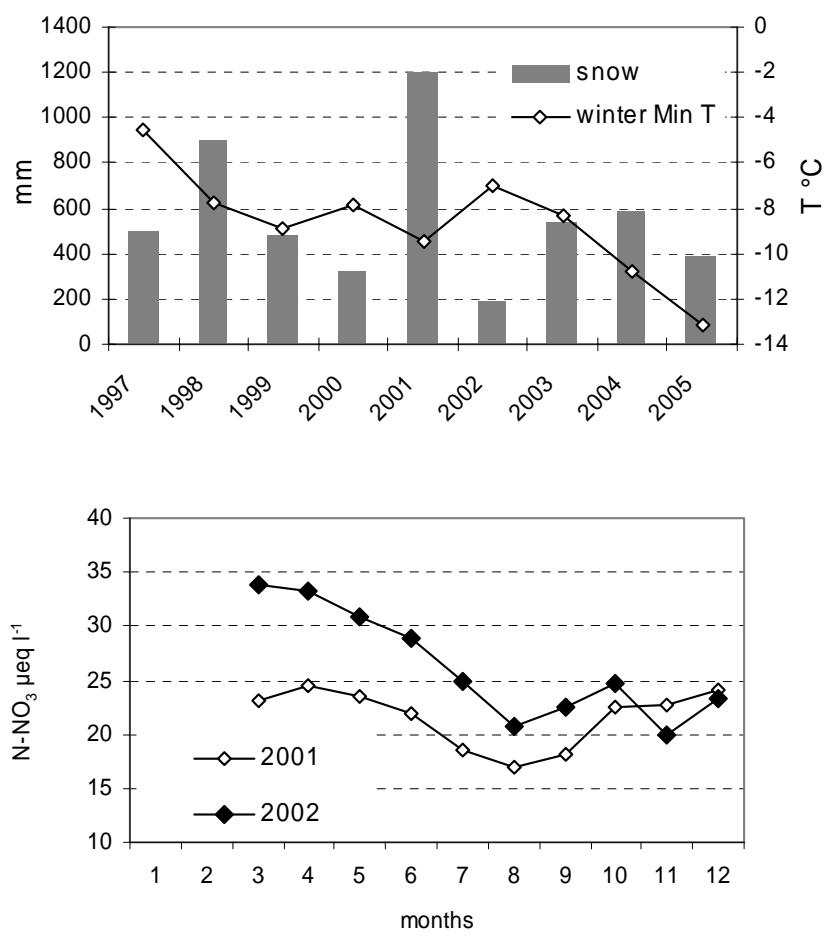

Fig. 4. Annual amounts of snow measured at the River Masino site during the winter period preceding the snowmelt along with minimum winter temperatures (above), and $\mathrm{NO}_{3}$ concentration patterns during 2001 and 2002 (below).

snowmelt-dominated hydrology (Likens et al., 1977; Weaver and Forcella, 1979). These pulses were attributed to the input of litterfall organic matter combined with a reduced plant uptake. The opposite behaviour observed at River Masino should also suggest a lower impact of the runoff from the forested part of the basin on stream chemistry.

Despite the lack of a significant correlation with air temperature, $\mathrm{NO}_{3}$ in River Masino showed some response to this variable, especially to extreme values: for instance the coldest winters of the study record (2004 and 2005) were followed by the highest $\mathrm{NO}_{3}$ peaks in spring months (Fig. 1). The low $\mathrm{N}$ retention capacity of frozen soils during cold winters can be hypothesised as the main cause for this pattern (Mitchell et al., 1996). Many authors found a link between the reduction of snow cover and the intensification of soil freezing and freeze/thaw cycles with consequences for the biological community (bacteria and roots) and therefore for the release of nutrients (Edward and Cresser, 1992; Brooks et al., 1996; Groffman et al., 1999). The annual amounts of snow measured in the Masino area during the winter period preceding the snowmelt is plotted in Fig. 4, along with the minimum winter temperatures. The $\mathrm{NO}_{3}$ concentration patterns during 2001 and 2002, respectively the most and least snowy year, exhibited remarkable differences (Fig. 4). $\mathrm{NO}_{3}$ values measured during the spring of 2001 were about $30 \%$ lower than those recorded the next year, and are the lowest
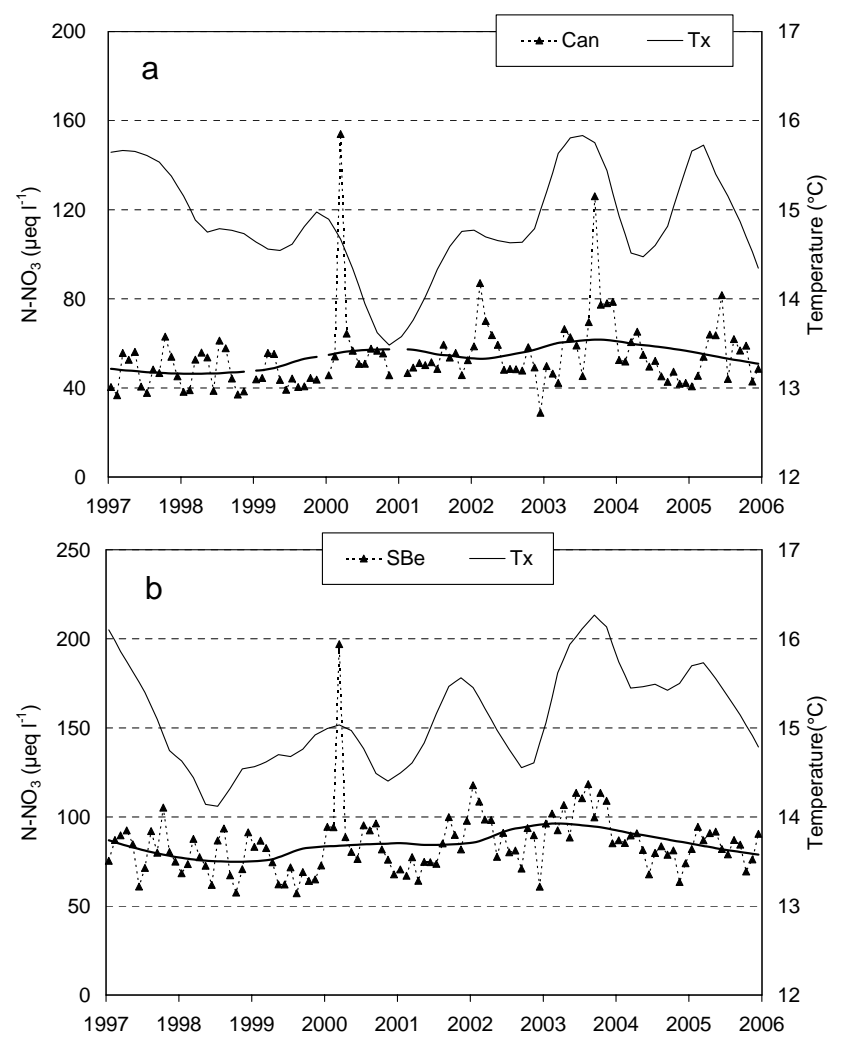

Fig. 5. Long-term dynamics and smoother (thick line) of monthly $\mathrm{NO}_{3}$ concentrations in River Cannobino (a) and S. Bernardino (b) plotted versus smoothed (repeated loess smoothing, span width 0.4 ) time series of maximum temperature (Tx).

of the whole study period (1997-2005). On the other hand, the 2002 values were close to the concentrations reached in 2004 and 2005 (Fig. 1).

An opposite response to extreme temperatures was found for the other study sites. The significant positive crosscorrelation between $\mathrm{NO}_{3}$ and maximum temperature in the Cannobino and the S. Bernardino $(\mathrm{CC}=0.29$ and 0.55 , respectively) lead to the hypothesis that temperature-dependent processes, such as mineralization and nitrification, explain $\mathrm{NO}_{3}$ pulses in the water of these rivers. $\mathrm{N}$ release from soils may derive from enhanced mineralisation and nitrification during warm periods (Van Breemen et al., 1998). A climate control on $\mathrm{NO}_{3}$ leaching through temperaturedependent processes is certainly relevant at $\mathrm{N}$ saturated sites. It is true that these processes may not affect the long-term trend in response to $\mathrm{N}$ deposition, but they may explain shortterm variability and eventually accelerate the trend over time (Murdoch et al., 1998). Monthly $\mathrm{NO}_{3}$ concentrations in Rivers Cannobino and S. Bernardino were plotted against the de-seasonalised time series of maximum temperature in Fig. 5. $\mathrm{NO}_{3}$ peaks recorded in the springs of 2000 and 2002 and in the summers of 2003 and 2005 in River Cannobino were preceded by warm periods, with temperature 
Table 4. Results of multiple linear regression (backward selection with a 0.05 significance threshold) applied to monthly data of $\mathrm{NO}_{3}$ and $\mathrm{SO}_{4}$ concentrations. Model selection based on the AIC. Significance levels: $* * * \mathrm{p}<0.001 ; * * \mathrm{p}<0.01 ; * \mathrm{p}<0.05$. Abbreviations as in Table 2 .

\begin{tabular}{|c|c|c|c|}
\hline \multicolumn{4}{|c|}{ Model: $\mathrm{NO}_{3}$ river $\sim \mathrm{mm}+\mathrm{Q}(\mathrm{Hidr})+\mathrm{NO}_{3}$ rain $+\mathrm{NO}_{3}$ dep $+\mathrm{Tn}+\mathrm{Tx}$} \\
\hline & Masino & Cannobino & S. Bernardino \\
\hline Coefficients (t and p-level) & $\operatorname{Tn}-7.082 * * * \operatorname{Tx} 6.011 * * *$ & $\operatorname{Tn}-1.968 * \operatorname{Tx} .2 .136 *$ & $\mathrm{Q}-2.853 * * \mathrm{Tn}-1.987 * \mathrm{Tx} 1.909 *$ \\
\hline Residual standard error & 4.341 on $64 \mathrm{DF}$ & 16.19 on $94 \mathrm{DF}$ & 17.19 on $95 \mathrm{DF}$ \\
\hline Multiple $\mathrm{R}^{2}$ & 0.470 & 0.046 & 0.127 \\
\hline p-value & $1.515 \mathrm{e}-09$ & 0.1076 & 0.0111 \\
\hline \multicolumn{4}{|c|}{ Model: $\mathrm{SO}_{4}$ river $\sim \mathrm{mm}+\mathrm{Q}(\mathrm{Hidr})+\mathrm{SO}_{4}$ rain $+\mathrm{SO}_{4} \mathrm{dep}+\mathrm{Tn}+\mathrm{Tx}$} \\
\hline & Masino & Cannobino & S. Bernardino \\
\hline Coefficients (t and p-level) & Hidr $-3.277 * * \mathrm{Tn}-9.792 * * * \mathrm{SO}_{4}$ rain $2.691 * *$ & $\mathrm{Q}-2.554 * *$ & $\mathrm{~mm} 3.209 * * \mathrm{Q}-5.670 * * *$ \\
\hline Residual standard error & 4.723 on $63 \mathrm{DF}$ & 20.44 on $94 \mathrm{DF}$ & 39.6 on $94 \mathrm{DF}$ \\
\hline Multiple $\mathrm{R}^{2}$ & 0.751 & 0.183 & 0.358 \\
\hline p-value & $<2.2 \mathrm{e}-16$ & $7.468 \mathrm{e}-05$ & $4.981 \mathrm{e}-08$ \\
\hline
\end{tabular}

values above the long-term mean for this area (Fig. 5a). A similar correspondence was observed in River S. Bernardino data (Fig. 5b), though without a less evident time lag between temperature increase and $\mathrm{NO}_{3}$ response than in the Cannobino.

$\mathrm{SO}_{4}$ in River Masino was partly controlled by atmospheric input, showing a positive relationship with $\mathrm{SO}_{4}$ concentration in rain and $\mathrm{SO}_{4}$ deposition $(\mathrm{CC}=0.54$ and 0.38 , respectively). The small catchment area, the steep slope favouring a rapid flushing of runoff water and the presence of a thin soil cover all contributed to a reduced exchange capacity between runoff water and soils in the Masino catchment. This could explain the rapid response of $\mathrm{SO}_{4}$ levels in running waters to $\mathrm{SO}_{4}$ deposition, as shown both by $\mathrm{CC}$ and trend analysis (Tables 2 and 3).

$\mathrm{SO}_{4}$ in River Cannobino, and to a lesser extent in River $\mathrm{S}$. Bernardino, was inversely related to precipitation amount $(\mathrm{CC}=-0.66$ and -0.36 , respectively) and positively correlated to temperature values.

As hypothesised for $\mathrm{NO}_{3}$ leaching, $\mathrm{SO}_{4}$ release from catchment soils may also be driven by temperaturedependent processes such as desorption and mineralisation of previously stored $\mathrm{SO}_{4}$ (Prechtel et al., 2001). Furthermore high temperature may enhance weathering of sulphurbearing minerals in rocks and soils, so leading to increasing $\mathrm{SO}_{4}$ export to surface waters. This effect could be of some importance in the Cannobino catchment, where weathering represents a non-negligible contribution of $\mathrm{SO}_{4}$ to river water (Rogora et al., 2001).

Multiple linear regression was applied to the monthly data to discover the best predictor variables for water chemistry at the various sites. Hydrology (precipitation amount and discharge), minimum and maximum temperatures and $\mathrm{NO}_{3}$ and $\mathrm{SO}_{4}$ deposition (both concentrations and fluxes) were used as explanatory variables. Model coefficients and the main statistical parameters are shown in Table 4.
The best model fitting was obtained with River Masino data: $\mathrm{SO}_{4}$ values were fairly well predicted by the hydrometric level, minimum temperature and $\mathrm{SO}_{4}$ concentration in rain. Minimum and maximum temperatures were the main predictors for $\mathrm{NO}_{3}$ concentrations, though the model fitting was significantly lower compared to that of $\mathrm{SO}_{4}$ (Table 4). Significant regression models, though with rather a poor fit, were obtained for $\mathrm{SO}_{4}$ concentrations in Rivers Cannobino and S. Bernardino, with discharge (and precipitation amount for the S. Bernardino) as the main predictor. On the other hand, the selected variables failed to model $\mathrm{NO}_{3}$ concentrations at these two sites (Table 4).

Generally speaking, the approach of empirical modelling by linear regression was not successful at the study sites. Only for River Masino chemical data were quite well predicted by meteorological and hydrological data, with temperature being the main driver of change. The atmospheric input also had some importance in $\mathrm{SO}_{4}$ fluctuations and trend at this site.

\section{Conclusions}

The analysis of river chemical data showed that $\mathrm{SO}_{4}$ concentrations were mainly driven by dilution and concentration processes. River Masino, exposed to the lowest $\mathrm{SO}_{4}$ loads, seems to have responded fairly well and rapidly to changes in hydrology and atmospheric input. The catchment characteristics, which prevent a significant interaction between runoff water and soils, have facilitated this process. Conversely, desorption of previously stored $\mathrm{SO}_{4}$ or other soil processes may account for some variations in $\mathrm{SO}_{4}$ levels in Rivers Cannobino and $\mathrm{S}$. Bernardino. Previous studies showed that $\mathrm{SO}_{4}$ levels in these rivers responded slowly to decreased deposition and the decrease was in any case less than the decline in input fluxes (Prechtel et al., 2001). Because temperature proved to be an important factor in the $\mathrm{SO}_{4}$ export from these 
river catchments to runoff water, climate warming may be delaying acidification recovery by enhancing $\mathrm{SO}_{4}$ desorption and increasing mineralisation in soils.

Unlike $\mathrm{SO}_{4}, \mathrm{NO}_{3}$ deposition has not shown a widespread decline in the alpine area (Rogora et al., 2006). Thus, a delay effect on recovery processes or even more a re-acidification effect can be expected from the $\mathrm{NO}_{3}$ leaching from soils to surface water, still in the less contaminated area of River Masino.

At $\mathrm{N}$ saturated sites such as the Cannobino and the $\mathrm{S}$. Bernardino, temperature-dependent processes such as mineralisation and nitrification in soils could play a major role in $\mathrm{NO}_{3}$ enrichment of surface waters in the near future. These temperature effects are not yet evident at River Masino, where biotic processes still have the major role in controlling the release of nitrate during the growing season. On the other hand, hydrological changes in autumn and winter proved to be the main driver of increasing $\mathrm{NO}_{3}$ in River Masino. At present, changes in precipitation regime and snow cover are probably more important than temperature variation in determining the $\mathrm{NO}_{3}$ temporal pattern at this site. But in the future, the temperature-dependent processes which are important at the other sites could add synergistically to the hydrological processes and cause an increase of $\mathrm{NO}_{3}$ also in the summer period.

According to future scenarios of global change, climate warming will be more pronounced in mountain areas than in lowland regions (IPCC, 2001). Increasing temperature together with changes in the rain to snow ratio will greatly affect the hydrological cycles at high-altitude sites (Haeberli and Beniston, 1998). Alpine rivers, like those considered here, could experience major changes in their hydrological regime in a changing climate. Scenarios provided by regional climate models and measured data available for some sites in the study region show a tendency towards reduced precipitation, mainly in winter and summer, and increasing occurrence of droughts (Rogora et al., 2004; Ambrosetti et al., 2006). According to our findings, both these two changes may strengthen the effect of chronic $\mathrm{N}$ deposition on surface water ecosystems.

A better understanding of climate change impact on the $\mathrm{N}$ cycle in these sensitive areas is of overwhelming importance. Along with long-term monitoring at key sites, in-depth investigations of the main biogeochemical processes at the catchment scale are needed to make reliable predictions of water response to atmospheric deposition in a changing climate.

Acknowledgements. This study was supported by the Eurolimpacs project (the Commission of European Communities GOCE-CT2003-505540) and by the National Research Council of Italy, in the framework of a Convention with the Ministry of the Environment for the management of the National Focal Centre of the ICP Waters. The studies in the Val Masino area were supported by the ERSAF (Regional Agency for Agricultural and Forest Service). We thank two anonymous reviewers for their helpful suggestions.
Edited by: P. Dillon and R. F. Wright

\section{References}

Aber, J. D. and Driscoll, C. T.: Effects of land use, climate variation and $\mathrm{N}$ deposition on $\mathrm{N}$ cycling and $\mathrm{C}$ storage in northern hardwood forests, Global Biogeochem. Cycles, 11(4), 639-648, 1997.

Aber, J. D., Ollinger, S. V., Driscoll, C. T., Likens, G. E., Holmes, R. T., Freuder, R. J., and Goodale, C. L.: Inorganic nitrogen losses from a forested ecosystem in response to physical, chemical, biotic, and climatic perturbations, Ecosystems, 5, 648-658, 2002.

Ambrosetti, W., Barbanti, L., and Rolla, A.: The climate of Lago Maggiore area during the last 50 years, J. Limnol., 65(1), 62 pp., 2006.

Arthur, M. A. and Fahey, T. J.: Control on soil solution chemistry in a subalpine forest in North-Central Colorado, Soil Sci. Soc. Am. J., 57, 1122-1130, 1993.

Balestrini, R. and Tagliaferri, A.: Atmospheric deposition and canopy exchange processes in alpine forest ecosystems (Northern Italy), Atmos. Environ., 35/36, 6421-6433, 2001.

Balestrini, R., Tagliaferri, A., Tartari, G., and Di Girolamo, F.: Forest condition and chemical characteristics of atmospheric depositions: research and monitoring network in Lombardy, in: Longterm ecological research in Italian forest ecosystems, edited by: Mosello, R., Petriccione, B., and Marchetto, A., J. Limnol., 61, 117-128, 2002.

Balestrini R., Di Martino, N., and Van Miegroet, H.: Nitrogen cycling and mass balance for a forested catchment in the Italian Alps, Biogeochemistry, 78, 97-123, 2006.

Brooks, P. D., Williams, M. W., and Schmidt, S. K.: Microbial activity under alpine snowpacks, Niwot Ridge, Colorado, Biogeochemistry, 32, 93-113, 1996.

Campbell, D. H., Clow, D. W., Ingersoll, G. P., Mast, M. A., Spahr, N. E., and Turk, J. T.: Processes controlling the chemistry of 2 snowmelt-dominated streams in the Rocky-Mountains, Water Resour. Res., 31, 2811-2821, 1995.

Cleveland, R. B., Cleveland, W. S., McRae, J. E., and Terpening, I.: STL: A Seasonal-Trend Decomposition Procedure Based on Loess, Journal of Official Statistics, 6, 3-73, 1990.

Creed, I. F., Band, L. E., Foster, N. W., Morrison, I. K., Nicolson, J. A., Semkin, R. S., and Jeffries, D. S.: Regulation of nitrate-N release from temperate forests: A test of the $\mathrm{N}$ flushing hypothesis, Water Resour. Res., 32, 3337-3354, 1996.

Edwards, A. C. and Cresser, M. S.: Freezing and its effect on chemical and biological properties of soil, Adv. Soil Sci., 18, 59-79, 1992.

Eimers, M. C. and Dillon, P. J.: Climate effects on sulphate flux from forested catchments in south-central Ontario, Biogeochemistry, 61, 337-355, 2002.

Evans, C. D., Cullen, J. M., Alewell, C., Kopácek, J., Marchetto, A., Moldan, F., Prechtel, A., Rogora, M., Veselý, J., and Wright, R. F.: Recovery from acidification in European surface waters, Hydrol. Earth Syst. Sci., 5, 283-297, 2001, http://www.hydrol-earth-syst-sci.net/5/283/2001/.

Foster, N. W., Nicolson, J. A., and Hazlett, P. W.: Temporal variation in nitrate and nutrient cations in drainage waters from a deciduous forest, J. Environ. Quality, 18, 238-244, 1989. 
Groffman, P. M., Hardy, J. P., Nolan, S., Driscoll, C. T., Fitzhugh, R. D., and Fahey, T. J.: Snow depth, soil frost and nutrient loss in a northern hardwood forest, Hydrol. Processes, 13, 2275-2286, 1999.

Haeberli, W. and Beniston, M.: Climate change and its impacts on glaciers and permafrost in the Alps, Ambio, 27, 258-265, 1998.

Hirsch, R. M., Slack, J. R., and Smith, R.: Techniques of trend analysis for monthly water quality data, Water Resour. Res., 18, 107-121, 1982.

Hirsch, R. M. and Slack, J. R.: A nonparametric trend test for seasonal data with serial dependence, Water Resour. Res., 20, 727732, 1984.

IPCC, Climate Change 2001: The Scientific Basis, Contribution of Working Group I to the Third Assessment Report of the Intergovernmental Panel on Climate Change (IPCC), in: Cambridge University Press, edited by: Houghton J. T., Ding, Y., Griggs, D. J., Noguer, M., van der Linden, P. J., and Xiaosu, D., UK, 944 pp., 2001.

Likens, G. E., Borman, F. H., Pierce, R. S., Eaton, J. S., and Johnson, N. M.: Biogeochemistry of a forested watershed, Springer, New York, 1977.

Lükewille, A. and Wright, R. F.: Experimentally increased soil temperature causes release of nitrogen at a boreal forest catchment in southern Norway, Global Change Biol., 3, 13-21, 1997.

Mitchell, M. J., Driscoll, C. T., Kahl, J. S., Likens, G. E., Murdoch, P. S., and Pardo, L. H.: Climatic control of nitrate losses from forested watersheds in the Northeast United States, Environ. Sci. Technol., 30, 2609-2612, 1996.

Mitchell, M. J., Driscoll, C. T., Inamdar, S., Mcgee, G. G., Mbila, M. O., and Raynal, D. J.: Nitrogen biogeochemistry in the Adirondack Mountains of New York: hardwood ecosystems and associated surface waters, Environ. Pollut., 123, 355-364, 2003.

Mitchell, M. J., Piatek, K. B., Christopher, S., Mayer, B., Kendall, C., and Mchale, P.: Solute Sources in Stream Water during Consecutive Fall Storms in a Northern Hardwood Forest Watershed: A Combined Hydrological, Chemical and Isotopic Approach, Biogeochemistry, 78, 217-246, 2006.

Mosello, R., Calderoni, A., Marchetto, A., Brizzio, M. C., Rogora, M., Passera, S., and Tartari, G. A.: Nitrogen budget of Lago Maggiore: the relative importance of atmospheric deposition and catchment sources, J. Limnol., 60, 27-40, 2001.

Mosello, R., Marchetto, A., Brizzio, M. C., Tartari, G. A., and Rogora, M., Pluriannual evolution of the hydrochemistry of two alpine lakes (Lake Paione Inferiore and Lake Paione Superiore, Ossola Valley) in relation to atmospheric loads, J. Limnol., 58, 43-49, 1999.

Murdoch, P. S., Burns D. A., and Lawrence, G. B.: Relation of climate change to the acidification of surface waters by nitrogen deposition, Environ. Sci. Technol., 32, 1642-1647, 1998.

Prechtel, A., Alewell, C., Armbruster, M., Bittersohl, J., Cullen, J. M., Evans, C. D., Helliwell, R., Kopácek, J., Marchetto, A., Matzner, E., Meesenburg, H., Moldan, F., Moritz, K., Veselý, J., and Wright, R. F.: Response of sulphur dynamics in European catchments to decreasing sulphate deposition, Hydrol. Earth Syst. Sci., 5, 311-325, 2001, http://www.hydrol-earth-syst-sci.net/5/311/2001/.
Reynolds, B., Emmett, B. A., and Woods, C.: Variations in streamwater nitrate concentrations and nitrogen budgets over 10 years in a headwater catchment in mid-Wales, J. Hydrol., 136, 155-75, 1992.

Rogora, M., Marchetto, A., and Mosello, R., Trends in the chemistry of atmospheric deposition and surface waters in the Lago Maggiore watershed, Hydrol. Earth Syst. Sci., 5, 379-390, 2001, http://www.hydrol-earth-syst-sci.net/5/379/2001/.

Rogora, M., Mosello, R., Arisci, S., Brizzio, M. C., Barbieri, A., Balestrini, R., Waldner, P., Schmitt, M., Stähli, M., Thimonier, A., Kalina, M., Puxbaum, H., Nickus, U., Ulrich, E., and Probst, A.: Atmospheric deposition on the Alps: effects on the functioning of the alpine and subalpine ecosystems, Hydrobiologia, 562, 17-40, 2006.

Rogora, M. and Mosello, R.: Climate as a confounding factor in the response of surface water to nitrogen deposition in an area South of the Alps, Appl. Geochem., 22, 1122-1128, 2007.

Rogora, M., Arisci, S., and Mosello, R.: Recent trends of temperature and precipitation in alpine and subalpine areas in North Western Italy, Geografia Fisica e Dinamica Quaternaria, 27, 151158, 2004.

Sen, P. K.: Estimates of the regression coefficient based on Kendall's tau, J. Am. Stat. Assoc., 63, 1379-1389, 1968.

Sickman, J. O., Leydecker, A., Chang, C. Y., Kendall, C., Melack, J. M., Lucero, D. M., and Schimel, J.: Mechanisms underlying export of $\mathrm{N}$ from high-elevation catchments during seasonal transitions, Biogeochemistry, 57/58, 341-374, 2002.

Skjelkvåle, B. L., Stoddard, J., Jeffries, D., Tørseth, K., Høgåsen, T., Bowman, J., Mannio, J., Monteith, D., Mosello, R., Rogora, M., Rzychon, D., Vesely, J., Wieting, J., Wilander, A., and Worsztynowicz, A.: Regional scale evidence for improvements in surface water chemistry 1990-2001, Environ. Pollut., 137, 165-176, 2005.

Stark, J. M. and Hart, S. C.: High rates of nitrification and nitrate turnover in undisturbed coniferous forests, Nature, 385, 1-64, 1997.

Stoddard, J. and Traaen, T.: The stages of nitrogen saturation: classification of catchments included in "ICP on Waters", in: Mapping and modelling of critical loads for nitrogen: a workshop report, edited by: Hornung, M., Stutton, M. A., and Wilson, R. B., Proceedings of a workshop held in Grange-over-sands (UK), 24-26 October 1994, 69-76, 1994.

Stottlemeyer, R.: Stream water chemistry in watersheds receiving different atmospheric inputs of $\mathrm{H}^{+}, \mathrm{NH}_{4}^{+}, \mathrm{NO}_{3}^{-}$, and $\mathrm{SO}_{4}^{2-}$, $\mathrm{J}$. Am. Water Resour. Assoc., 33, 767-779, 1997.

Van Breemen, N., Jenkins, A., Wright, R. F., Beerling, D. J., Arp, W. J., Berendse, F., Beier, C., Collins, R., van Dam, D., Rasmussen, L., Verburg, P. S. J., and Wills, M. A.: Impacts of Elevated Carbon Dioxide and Temperature on a Boreal Forest Ecosystem (CLIMEX Project), Ecosystems, 1, 345-351, 1998.

Weaver, T. and Forcella, F.: Seasonal variation in soil nutrients under six Rocky Mountain vegetation types, Soil Sci. Soc. Am. J., 43, 589-593, 1979.

Wright, R. F.: Effect of Increased Carbon Dioxide and Temperature on Runoff Chemistry at a Forested Catchment in Southern Norway (CLIMEX Project), Ecosystems, 1, 216-225, 1998. 